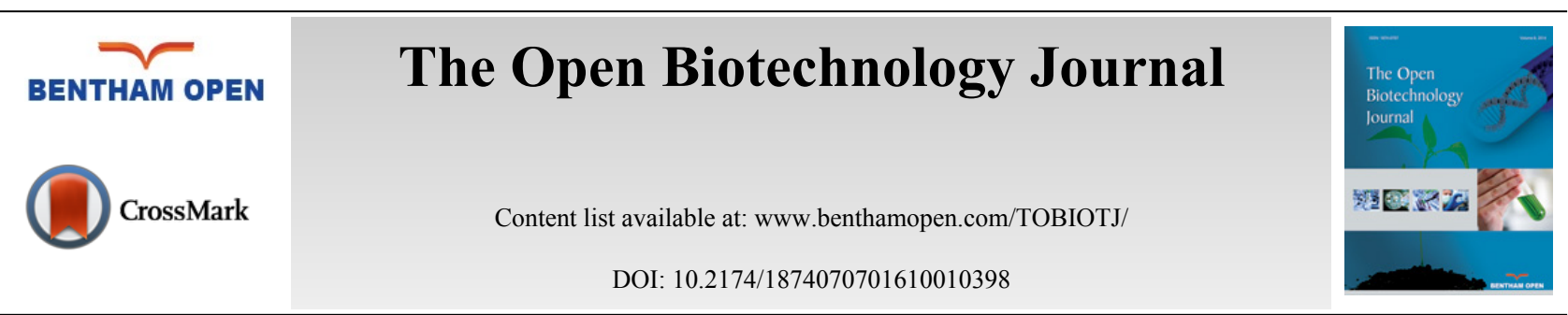

REVIEW ARTICLE

\title{
Overview on Electricigens for Microbial Fuel Cell
}

\author{
Li-ping Fan $^{1, *}$ and Song Xue ${ }^{2}$ \\ ${ }^{I}$ College of Information Engineering, Shenyang University of Chemical Technology, Shenyang, 110142, China \\ ${ }^{2}$ College of Environment and Safety Engineering, Shenyang University of Chemical Technology, Shenyang 110142, \\ China
}

\begin{abstract}
Microbial fuel cell is a bio-electrochemical system that drives a current by using bacteria and mimicking bacterial interactions found in nature. The electricigens and its activity have important influence on the power generation capacity and organic matter degradation ability of MFC system. The common types of electricigens and their application situation in microbial fuel cell are summarized in this paper, the basic characteristics and electron transfer mechanism of some major microorganisms are described, so as to provide some ideas for electricigens' selection, transformation and optimization of a variety of strains to improve the power generation capacity and organic matter degradation ability of MFC system.
\end{abstract}

Keywords: Degradation ability, Electricigens, Microbial fuel cell, Power generation capacity, Wastewater treatment.

\section{INTRODUCTION}

Depletion of conventional energy sources and also its negative effect on environment has led many researchers to look for alternative energy sources. Developing carbon-neutral renewable energy sources is an important research area for alternative power systems.

Microbial fuel cell (MFC) is a kind of biological chemical reaction device that can directly convert the chemical energy stored in organic matter into electrical energy by using microbial metabolic activity. MFC produces electricity while purifying wastewater and cause hardly any pollution to the environment during the power generation process. It is regarded as a new wastewater treatment process and a new green power generation technology which has the advantages of high efficiency, low energy consumption, clean and environmental protection [1 - 4].

Electricigens are a kind of microorganism which can completely oxidize the organic matter by using the electrode as the sole electron acceptor. They are essential for the bioelectrochemical processes in MFCs [5]. A typical MFC is a twochambered system containing an anode chamber and a cathode chamber separated by an ion permeable membrane $[6,7]$. Electricigens in the anode chamber oxidize organic matter to release electrons to the anode electrode. Electrons donated to the anode flow to the cathode through electrical wires, where they are reunited with the protons generated in the anode chamber and combine with oxygen or other electron acceptors to form reduced product.

Various types of microbes have been used in MFCs. A major challenge to the development of MFC as a novel electricity generating technology is harnessing the linkage of electricigens to the electrode substrate via electron transport. To prove up the species distribution, growth characteristics, metabolic characteristics and electricity mechanism of electricigens will contribute to the development of MFC.

This paper makes a simple overview on some common electricigens for MFCs.

\footnotetext{
"Address correspondence to this author at the College of Information Engineering, Shenyang University of Chemical Technology, Shenyang, 110142, China; Tel/Fax: 86-24-89386011; E-mails: flpsd@163.com, fanliping@syuct.edu.cn
} 


\section{COMMON TYPES OF ELECTRICIGENS}

\subsection{Escherichia coli}

Escherichia coli (E. coli) is one of the gram negative bacteria that can ferment most sugars, and it is facultative anaerobic. E. coli produces a large quantity of indole in a stationary phase, which functions as an extracellular signal to control diverse aspects of bacterial physiology. In MFC, indole was utilized as a carbon source in a mixture of culture and enhanced power generation in an MFC [8]. After domestication, power production capacity of E.coli increased significantly. E coli has been used as bacterial strain in many MFCs [9 - 13]. E coli can self-mediate the extracellular electron transfer to electrode in fuel cell through the electrochemically activated excretion of electron shuttling molecules, and it can catalyze the glucose oxidation in fuel cell anode in the absence of any artificial electron mediators [14]. Researches show that MFCs catalyzed by the evolved or engineered E. coli deliver much higher power density, reduce operation expense and eliminate toxic effects of artificial mediators [15].

$E$. coli has the advantages of easy access, easy cultivation, low cost, safety, and metabolizing a variety of substrates. The use of E. coli as the electricigens of MFC has great application prospects.

\subsection{Shewanella}

Shewanella are well known for the diversity of terminal electron acceptors they can reduce and are one of the primary families of bacteria used in MFCs [16], and their capacity to release electron shuttling out of cells, which help them transfer electrons to electrodes without direct contact. Shewanella are facultative gram-negative anaerobes inhabiting a wide variety of niches in nature where they degrade diverse organic compounds and utilize a broad spectrum of electron acceptors for growth under anaerobic conditions.

Shewanella have become one of the most important electricity producing microorganisms due to their respiratory type diversity [17]. Bacteria of the groups Shewanellaceae and Geobacteraceae are classic models in MFC research because of the breadth of knowledge about their metabolism and versatility [18]. Shewanella can generate nano wire to transfer the electron to the electrode directly, so the anode has a high conductivity even if multilayer cells biofilm accumulate on it [19].

Shewanella fuel cell is the earliest available mediator-less microbial fuel cell. In 1999, Kim et al. used Shewanella in MFC and realized electricity production in the absence of exogenous mediators, which lift the curtain on researching the mediator-less MFC [20]. The importance of Shewanella as potential bioelectrochemical catalysts for MFC technology continues to drive research into the adaptability of Shewanella for power production. Various Shewanella strains were developed as electrogenic biocatalysts in MFCs, and intensive studies were conducted to understand the mechanism of electron transfer to electrode using Shewanella oneidensis MR-1 as a model microorganism [21].

\subsection{Enterococcus faecalis}

Enterococcus faecalis (E. faecalis) is generally defined as a class of gram positive bacteria isolated from feces and used for isolation and identification of nitrogen sodium. E. faecalis is facultative anaerobic. Xie separated a strain of $E$. faecalis from acclimation mangrove sediment, and its characteristics of electricity generation were investigated. The experimental results show that the electricity generation capacity of MFC with E. faecalis is higher than that of MFC with Shewanella [22]. Cui studied the characteristics of electricity generation by E. faecalis, and validated the optimum growth temperature, and showed that the contact of bacteria and electrode is the essential factor of electricity production [23]. In Zhang et al.'s study, E. faecalis was employed in microbial fuel cells, bacterial biofilms formed by E. faecalis were investigated with respect to electricity production, and showed that trace riboflavin was essential for transferring electrons in the absence of other potential electron mediator. E. faecalis can resist the external environment, and has strong resistance and adaption to temperature, even can resist many kinds of antibiotics [24].

\subsection{Geobacter}

Geobacter $(G$.) is a very important kind of electricigens, and it is gram-positive anaerobes. Amongst many known bacteria which can produce electricity, the most successful as of today are the Geobacter species [25]. Researches show that if a platinum or graphite electrode is inserted into seawater sediments and anther electrode linked together with it is inserted in water with rich dissolved oxygen, a continuous current will produce. This is because Geobacter is highly enriched on the electrode [26 - 28]. Some Geobacter species also showed direct electron transferring properties [29], they can completely oxidize electron donor by using electrode as the only electron acceptor [30]. So far, Geobacter 
which was found to be able to use electrode as the only electron acceptor contains G. Metallireducens, Desulfuromonas acetoxidans, G. sulfurreducens, G. psychrophilus and Geopsychrobacter electrodiphilus [31]. Because the testing of the complete genome sequence of $G$. sulfurreducens has been completed, G. sulfurreducens is generally used as a model strain for microbial fuel cell research.

\subsection{Sulfate Reducing Bacteria}

Sulfate-rich waters are often found around the world as waste products from many mining, industrial processes or natural chemical reaction. The sulfate reducing bacteria $(S R B)$ can convert sulfate in anaerobic environment. Under anaerobic conditions, dissimilatory $S R B$ use sulfate as a terminal electron acceptor for the degradation of organic compounds, and the potential possibilities for conversion and storage of the energy obtained by $S R B$ are more and more attractive [32]. $S R B$ are heterotrophic bacteria that consume organic compounds as carbon and energy sources. A few studies proposed the use of $S R B$ to remove sulfate from wastewater with MFC [33]. Zhao et al. have developed a MFC for removal of sulfur-based pollutants and for simultaneous wastewater treatment and electricity generation [34], and they also have clarified that the generation of electricity in MFC using $S R B$ is mainly from the oxidation of biologically produced sulfide to elemental sulfur [35].

\subsection{Rhodoferax ferrireducens}

Rhodoferax ferrireducens ( $R$. ferrireducens) is able to metabolize sugar into electricity conversion, and conversion efficiency can reach above $80 \%$. $R$. ferrireducens is a facultative gram-negative anaerobic iron reducing microorganisms, which can directly transfer electrons to the electrode without requirement of a catalyst [36]. Compared with other MFCs, the most important advantage of $R$. ferrireducens MFC is that it transforms sugars into electrical energy effectively, thus greatly promotes the practical application process of microbial fuel cells. Liu et al. selected $R$. ferrireducens as electricigens, and studies the effective degradation of the sugar microbial biomass and the electricity generation performance of the MFC. Through the recycling experiment and biomass utilization experiment, the MFC constructed by $R$. ferrireducens is verified to be similar to an ideal two rechargeable battery [37]. Li et al. also constructed a MFC by using $R$. ferrireducens as electricigens, and experiments showed that the $R$. ferrireducens MFC has the advantages of normal temperature power generation, good cycle and so on [38].

\subsection{Saccharomyces cerevisiae}

Saccharomyces is widely distributed in nature as a kind of fungus. According to its distribution, Saccharomyces suits to grow in acidic environment with high sugar, has a strong resistance to osmotic pressure, a good resistance to high concentrations of sulfate, and resistance to high ammonia nitrogen. Thus MFC using Saccharomyces as electricigens is promising for treating high concentration organic wastewater. In MFC, Saccharomyces Cerevisiae is the most used Saccharomyces. Fatemi et al. used Saccharomyces cerevisiae as a pure culture in MFC [39]; Mathuriya et al. demonstrated the comparative electricity production capacity of Saccharomyces Cerevisiae and Clostridium acetobutylicum in two chambered MFC using artificial wastewater, and drew a conclusion that both Saccharomyces cerevisiae and Clostridium acetobutylicum are good candidate for bioelectricity production via MFC technology [40]; Rossi et al. found that the rate of substrate consumption by Saccharomyces Cerevisiae in the anaerobic compartment of a dual chambered MFC presented a great potential to generate electrons in a microbial fuel cell [41]; Arbianti et al. testified that microbial cultures of Saccharomyces cerevisiae can be used to produce electrical energy alternatives in MFC system, and also found that the media glucose yeast extract (GYE) is the most optimum medium for growth of Saccharomyces cerevisiae [42]; Gunawardena's research also show that Saccharomyces cerevisiae performed favorably as the bio-catalyst in a glucose powered microbial fuel cell [43]. In Rahimnejad's experiments, several microorganisms such as Pseudomonas putida, Saccharomyces cerevisiae, Lactobacillus bulgaricus, Escherichia coli and Aspergillus niger were cultured in an anaerobic chamber for the generation of electrons. The rate of substrate consumption in the anaerobic compartment indicated that Saccharomyces cerevisiae had the great potential to generate electrons [44].

\subsection{Pseudomonas aeruginosa}

Pseudomonas aeruginosa is widely distributed in nature, and is one of the most common bacteria in the soil. Pyocyanine excreted by Pseudomonas aeruginosa can be used as the electronic intermediaries for anodic reaction. Pyocyanine can be reduced by bacteria, and the reduced Pyocyanine will transfer electrons to the electrode to oxidize. The process will continue to cycle, and then electron transfer between the electrode and the thalli is achieved [45]. When using Pseudomonas aeruginosa to degrade quinolone, the MFC is more effective than the conventional anaerobic 
culture method [46]. Study clearly indicates that Pseudomonas aeruginosa can metabolize chicken feathers as a source of carbon and nitrogen, and chicken feathers can be successfully employed for electricity generation using MFC technology [47]. The optimal operating conditions of MFC with Pseudomonas aeruginosa F026 as electricigens are derived by experiments as: soluble starch as substrate, running temperature $35^{\circ} \mathrm{C}$, and $\mathrm{pH}$ was neutral and alkaline [48], and tests with pure cultures have shown that the addition of these compounds in MFCs can increase power [49].

\subsection{Some other Electricigens}

Some other electricigens used in MFC can also be found in reports. For example, the MFC based on the $\mathrm{Fe}(I I I)-$ reducing bacteria has the advantages as there is no need of any additional medium, a variety of organic electron donors can be used as fuel, higher energy conversion efficiency [50]; the Lactobacillus bulgaricus MFC system produced quantifiable amounts of electricity [51]; Ochrobactrum anthropic produced current using a wide range of substrates, including acetate, lactate, propionate, butyrate, glucose, sucrose, cellobiose, glycerol, and ethanol [52]; the mechanism of electron transfer in an MFC system was studied by using Klebsiella pneumoniae as biocatalyst [53]; Geopsychrobacter electrodiphilus may serve as important model organism for further elucidation of the mechanisms of microbe-electrode electron transfer in sediment fuel cells [54], Clostridium butyricum can produce electricity by using starch, molasses, glucose and lactic acid [55].

The basic characteristics of some common electricigens for MFC are shown in Table $\mathbf{1 .}$

Table 1. Basic characteristics of some common electricigens.

\begin{tabular}{|c|c|c|c|}
\hline Electricigens & Aerobic/anaerobic & Gram staining & Electron transfer \\
\hline E. coli & facultative anaerobic & negative & direct \\
\hline Shewanella & anaerobic & negative & indirect \\
\hline E. faecalis & facultative anaerobic & positive & direct \\
\hline Geobacter & anaerobic & positive & direct \\
\hline$S R B$ & anaerobic & negative & direct \\
\hline R. ferrireducens & facultative anaerobic & negative & direct \\
\hline Saccharomyces cerevisiae & anaerobic & 1 & direct \\
\hline Pseudomonas aeruginosa & aerobic & negative & direct \\
\hline
\end{tabular}

\section{ELECTRON TRANSFER MECHANISM OF ELECTRICIGENS}

\subsection{Electron Transfer from the Inside to the Outside of the Cell}

The electron transfer from the cell to the extracellular involves two steps: (1) electron transfer from the cytoplasma membrane to the outer membrane of the cell; (2) Electron transfer from the outer membrane to the extracellular electron acceptor. Most of the electricigens, such as Geobacter, can directly oxidize small molecules organic acids by dehydrogenase on its membrane and transfer the released electrons to the electron acceptor on the membrane. Some other electricigens, such as R. ferrireducen, Shewanella, can oxidize organic compounds such as sugars to generate reducing power $(\mathrm{NADH})$; subsequently, the electrons are transferred from NADH to the electron transport chain (metabolic respiratory chain) under the action of NADH dehydrogenase, which is then released to the outside of the cell by the respiratory chain. At present, NADH dehydrogenase, quinones, flavine enzyme and cytochrome $\mathrm{C}$ on the cell membrane are all key components of the electron transport system, and play an important role in the electron transfer process from the cell to the extracellular medium [56].

\subsection{Extracellular Electron Transfer}

It is generally regarded that there are two extracellular electron transfer (EET) mechanisms: direct electron transfer or indirect electron transfer.

\subsubsection{Direct Electron Transfer}

The direct electron transfer (DET) takes place via a physical contact of the bacterial cell membrane or a membrane organelle with the fuel cell anode, with no diffusional redox species being involved in the electron transfer from the cell to the electrode $[57,58]$. This typically occurs over short distances and requires cells to be in close proximity to the electrode. The experimental results presented evidence for direct electron transfer by a gram-positive bacterium 
Geobacter sp. [59]. The electron produced by the metabolism process can be transferred to the electrode through the cytochrome only if the bacteria that grow on the surface of the electrode can contact cytolemma to the surface of the electrode [60]. Electronic medium is a kind of inorganic or organic small molecule that can be involved in the oxidation and reduction system. When the medium is in a state of oxidation, it can be used as the electron acceptor for cell to send electrons to the electrode surface. Nano wires (Nanowire) can directly contact with solid iron oxide and pass the electrons from the bacteria to Fe (III). At present, the nanowires with electronic transmission functions have been found in many kinds of bacterial strain such as Shewanella [61], Geobacter [62, 63]. It is speculated that the nanowire is a widespread phenomenon in microorganisms.

\subsubsection{Indirect Electron Transfer}

Extracellular electron transfer achieved through the soluble endogenous redox mediator is regarded as the indirect electron transfer (IET) or mediated electron transfer (MET). There are a lot of endogenous electronic intermediary known, including phenazine, emodin, riboflavin, quinones, melanin etc. [64]. For example, Pseudomonas aeruginosa can transfer electrons to anode through electronic intermediary pyocyanin and phenazine-1-amide; Shewanella can use endogenous lutein as an electron mediator for electron shuttle [65].

Models for electron transfer mechanism are shown in Fig. (1) [66].

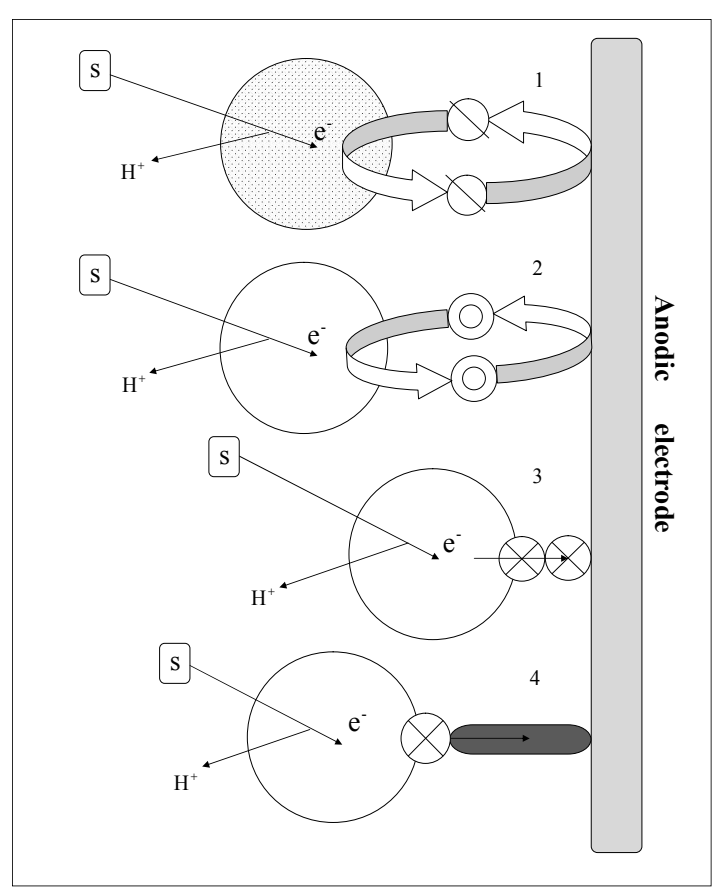

a) Electron transfer model has been established

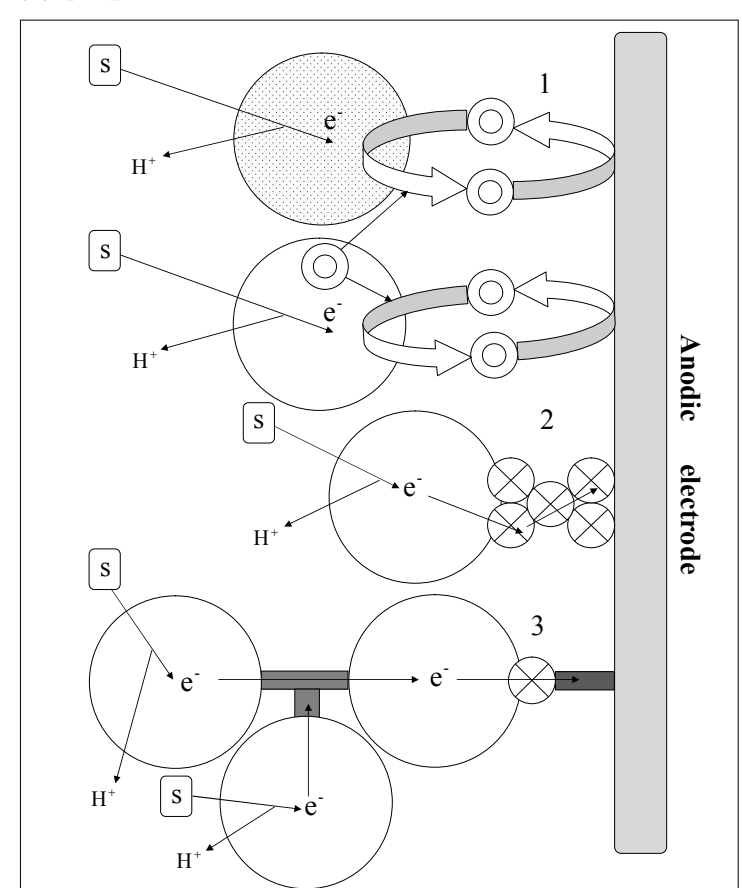

b) Electron transport model proposed recently

$$
\begin{array}{ll}
\text { Non-electroactive bacteria } & \bigotimes \text { Outer membrane cytochrome } \\
\bigcirc \text { Electroactive bacteria } & Q \text { Externally added mediators } \\
\text { () Self-produced mediators } & \text { Nanowire }
\end{array}
$$

Fig. (1). Models for electron transfer mechanism in anode.

\section{CONCLUSION}

The ability of microorganism to produce electricity varies greatly, and every electron transfer path has its advantages and disadvantages. Deep understanding on electricigens and their electron transfer mechanism will help to provide more effective methods to improve the performances of MFCs. The future work will focus on finding or culturing more efficacious electricigens for using in MFC. 


\section{CONFLICT OF INTEREST}

The authors confirm that this article content has no conflict of interest.

\section{ACKNOWLEDGEMENTS}

This work was supported by the Science and Technology special fund of Shenyang City under Grant F14-207-6-00, and the Chinese-Macedonian Scientific and Technological Cooperation Project of Ministry of Science and Technology of the People's Republic of China under Grant [2016] 10: 4-4.

\section{REFERENCES}

[1] Pandey BK, Mishra V, Agrawal S. Production of bio-electricity during wastewater treatment using a single chamber microbial fuel cell. Int J Eng Sci Technol 2011; 3: 42-7. [http://dx.doi.org/10.4314/ijest.v3i4.68540]

[2] Huggins T, Fallgren PH, Jin S, et al. Energy and performance comparison of microbial fuel cell and conventional aeration treating of wastewater. J Microbial Biochem Technol 2013; S6: 1-5.

[3] Nwokocha JV, Nwokocha NJ, Nnanna LA. The microbial fuel cell: the solution to the global energy and environmental crises. Int J Acad Res Prog Edu Dev 2012; 1: 363-74.

[4] Zhou MH, Chi ML, Luo JM, et al. An overview of electrode materials in microbial fuel cells. J Power Sources 2011; 196 : $4427-35$. [http://dx.doi.org/10.1016/j.jpowsour.2011.01.012]

[5] Vilajeliu-Pons A, Bañeras L, Puig S, et al. External resistances applied to mfc affect core microbiome and swine manure treatment efficiencies. PLoS One 2016; 11(10): e0164044. [http://dx.doi.org/10.1371/journal.pone.0164044] [PMID: 27701451]

[6] Logan BE, Hamelers B, Rozendal R, et al. Microbial fuel cells: methodology and technology. Environ Sci Technol 2006; 40(17): 5181-92. [http://dx.doi.org/10.1021/es0605016] [PMID: 16999087]

[7] Semenec L, Franks AE. The microbiology of microbial electrolysis cells. Microbiol Aust 2014; 11: 201-6. [http://dx.doi.org/10.1071/MA14065]

[8] Han TH, Cho MH, Lee J. Indole oxidation enhances electricity production in an E. coli-catalyzed microbial fuel cell. Biotechnol Bioproc E 2014; 19: 126-31.

[http://dx.doi.org/10.1007/s12257-013-0429-7]

[9] Masih SA, Devasahayam M, Zimik M. Optimization of power generation in a dual chambered aerated membrane microbial fuel cell with $E$ coli as biocatalyst. J Sci Ind Res (India) 2012; 71(9): 621-6.

[10] Xi M, Sun Y. Preliminary Study on E. coli microbial fuel cell and on-electrode taming of the biocatalyst. Chin J Process Eng 2008; 8: $1179-84$.

[11] Zhao CE, Chen J, Ding Y, et al. Chemically functionalized conjugated oligoelectrolyte nanoparticles for enhancement of current generation in microbial fuel cells. ACS Appl Mater Interfaces 2015; 7(26): 14501-5. [http://dx.doi.org/10.1021/acsami.5b03990] [PMID: 26079170]

[12] Chen XF, Wang XS, Liao K, et al. Improved power output by incorporating polyvinyl alcohol into the anode of a microbial fuel cell. J Mater Chem A Mater Energy Sustain 2015; 3: 19402-9. [http://dx.doi.org/10.1039/C5TA03318G]

[13] Liu J, Yong YC, Song H, et al. Activation enhancement of citric acid cycle to promote bioelectrocatalytic activity of arcA knockout Escherichia coli toward high-performance microbial fuel cell. ACS Catal 2012; 2: 1749-52. [http://dx.doi.org/10.1021/cs3003808]

[14] Zhang T, Cui C, Chen S, et al. The direct electrocatalysis of Escherichia coli through electroactivated excretion in microbial fuel cell. Electrochem Commun 2008; 10: 293-7. [http://dx.doi.org/10.1016/j.elecom.2007.12.009]

[15] Reiche A, Kirkwood KM. Comparison of Escherichia coli and anaerobic consortia derived from compost as anodic biocatalysts in a glyceroloxidizing microbial fuel cell. Bioresour Technol 2012; 123: 318-23. [http://dx.doi.org/10.1016/j.biortech.2012.07.005] [PMID: 22940336]

[16] Biffinger JC, Pietron J, Bretschger O, et al. The influence of acidity on microbial fuel cells containing Shewanella oneidensis. Biosens Bioelectron 2008; 24(4): 906-11.

[http://dx.doi.org/10.1016/j.bios.2008.07.034] [PMID: 18774288]

[17] Ni C, Chen BY, Wu YX, et al. Feasibility study of simultaneous bioelectricity generation and reductive decolorization using Shewanella xiamenensis BC01 in dula-chamber microbial fuel cells. J Xiamen Univ 2014; 53: 404-12. [Matural Science].

[18] Biffinger JC, Fitzgerald LA, Ray R, et al. The utility of Shewanella japonica for microbial fuel cells. Bioresour Technol 2011 ; $102(1)$ : 290-7. [http://dx.doi.org/10.1016/j.biortech.2010.06.078] [PMID: 20663660]

[19] Li DL, Xu MY, Sun GP. Electricity generated by Shewanella decolorationnis s12 in microbial fuel cell. Microbiology 2008; 35: 777-81. 
[20] Kim BH, Kim HJ, Hyun MS, et al. Direct electrode reaction of Fe(III)-reducing bacterium, Shewanella putrefaciens. J Microbiol Biotechnol 1999; 9(2): 127-31.

[21] Lanthier M, Gregory KB, Lovley DR. Growth with high planktonic biomass in Shewanella oneidensis fuel cells. FEMS Microbiol Lett 2008; 278(1): 29-35.

[http://dx.doi.org/10.1111/j.1574-6968.2007.00964.x] [PMID: 17995953]

[22] Xie H. Shewanella haliotis Z4 and Enterococcus faecalis In: Z5 and their characteristics of electricity generation (in China). Changsha, China: South China University of Technology 2012; p. 45.

[23] Cui Y. Study on the electrical properties of the Enterococcus faecalis. Yangzhou, China: Yangzhou Universiry 2013; p. 50.

[24] Zhang E, Cai Y, Luo Y, Piao Z. Riboflavin-shuttled extracellular electron transfer from Enterococcus faecalis to electrodes in microbial fuel cells. Can J Microbiol 2014; 60(11): 753-9. [http://dx.doi.org/10.1139/cjm-2014-0389] [PMID: 25345758]

[25] Poddar S, Khurana S. Geobacter: The electric microbe. Efficient microbial fuel cells to generate clean, cheap electricity. Indian J Microbiol 2011; 51(2): 240-1.

[http://dx.doi.org/10.1007/s12088-011-0180-8] [PMID: 22654173]

[26] Reimers CE, Tender LM, Fertig S, Wang W. Harvesting energy from the marine sedimentwater interface. Environ Sci Technol 2001; 35(1): 192-5. [http://dx.doi.org/10.1021/es001223s] [PMID: 11352010]

[27] Bond DR, Holmes DE, Tender LM, Lovley DR. Electrode-reducing microorganisms that harvest energy from marine sediments. Science 2002; 295(5554): 483-5. [http://dx.doi.org/10.1126/science.1066771] [PMID: 11799240]

[28] Kim MS, Cha J, Kim DH. Enhancing factors of electricity generation in a microbial fuel cell using Geobacter sulfurreducens. J Microbiol Biotechnol 2012; 22(10): 1395-400.

[http://dx.doi.org/10.4014/jmb.1204.04010] [PMID: 23075791]

[29] Schaetzle O, Barriere F, Baronian K. Bacteria and yeasts as catalysts in microbial fuel cells: electron transfer from micro-organisms to electrodes for green electricity. Energy Environ Sci 2008; 1: 607-20. [http://dx.doi.org/10.1039/b810642h]

[30] Bond DR, Lovley DR. Electricity production by Geobacter sulfurreducens attached to electrodes. Appl Environ Microbiol 2003; 69(3): 1548-55.

[http://dx.doi.org/10.1128/AEM.69.3.1548-1555.2003] [PMID: 12620842]

[31] Hong YG, Guo J, Sun GP. Recenct progress in electricigens and microbial fuel cell. Wei Sheng Wu Xue Bao 2007; 47(1): $173-7$. [PMID: 17436648]

[32] Angelov A, Bratkova S, Loukanov A. Microbial fuel cell based on electroactive sulfate-reducing biofilm. Energy Convers Manage 2013; 67: 283-6.

[http://dx.doi.org/10.1016/j.enconman.2012.11.024]

[33] Lee DJ, Liu X, Weng HL. Sulfate and organic carbon removal by microbial fuel cell with sulfate-reducing bacteria and sulfide-oxidising bacteria anodic biofilm. Bioresour Technol 2014; 156: 14-9. [http://dx.doi.org/10.1016/j.biortech.2013.12.129] [PMID: 24480414]

[34] Zhao F, Rahunen N, Varcoe JR, et al. Factors affecting the performance of microbial fuel cells for sulfur pollutants removal. Biosens Bioelectron 2009; 24(7): 1931-6. [http://dx.doi.org/10.1016/j.bios.2008.09.030] [PMID: 19022647]

[35] Zhao F, Rahunen N, Varcoe JR, et al. Activated carbon cloth as anode for sulfate removal in a microbial fuel cell. Environ Sci Technol 2008; 42(13): 4971-6. [http://dx.doi.org/10.1021/es8003766] [PMID: 18678035]

[36] Chaudhuri SK, Lovley DR. Electricity generation by direct oxidation of glucose in mediatorless microbial fuel cells. Nat Biotechnol 2003; 21(10): 1229-32. [http://dx.doi.org/10.1038/nbt867] [PMID: 12960964]

[37] Liu ZD, Lian J, Du ZW, Li HR. Construction of sugar-based microbial fuel cells by dissimilatory metal reduction bacteria. Sheng Wu Gong Cheng Xue Bao 2006; 22(1): 131-7. [http://dx.doi.org/10.1016/S1872-2075(06)60010-1] [PMID: 16572853]

[38] Li S, Du Z, Zhu X, et al. Catalytic efficiency of vanadyl compound in a microbial fuel cell constructed with Rhodoferax ferrireducens (in China). Chinese J Process Eng 2007; 7: 589-93.

[39] Fatemi S, Ghoreyshi AA, Najafpour G, et al. Bioelectricity generation in mediator-less microbial fuel cell: application of pure and mixed cultures. Iran J Energy Environ 2012; 3: 104-8.

[40] Mathuriya AS, Sharma VN. Electricity generation by Saccharomyces Cerevisiae and Clostridium acetobutylicumvia microbial fuel cell technology: a comparative study. Adv Biol Res (Faisalabad) 2010; 4: 217-23.

[41] Rossi R, Fedrigucci A, Setti L. Characterization of electron mediated microbial fuel cell by Saccharomyces cerevisiae. Chem Eng Trans 2015; 
43: $337-42$.

[42] Arbiant R, Hermansyah H, Utami TS. The usage of Saccharomyces cerevisiae in microbial fuel cell system for electricity energy production. Chem Eng J 2012; 6: 814-9.

[43] Gunawardena A, Fernando S, To F. Performance of a yeast-mediated biological fuel cell. Int J Mol Sci 2008; 9(10): $1893-907$. [http://dx.doi.org/10.3390/ijms9101893] [PMID: 19325724]

[44] Rahimnejad M, Mokhtarian N, Najafpour GD, et al. Low voltage power generation in a biofuel cell using anaerobic cultures. World Appl Sci J 2009; 6: 1585-8.

[45] Cao C, Chen L, Wu R, et al. Effecting of dissolved oxygen on microbial fuel cells based on Pseudomonas aeruginosa. J Electrochem 2014; 20: $382-5$.

[46] Chen S, Zhang C, Liu G, et al. Electricity generation and quinolone degradation by an electrochemically active bacterium, Pseudomonas citronellolis strain Q1. J Environ Sci (China) 2010; 30: 1130-7.

[47] Chaturvedi V, Verma P. Metabolism of chicken feathers and concomitant electricity generation by Pseudomonas aeruginosa by employing microbial fuel cell (MFC). J Waste Manage 2014. Article ID 928618, 9 pages [http://dx.doi.org/10.1155/2014/928618]

[48] Fei J, Teng Y, Xiong L, et al. Electricity generation performances of pseudomonas F026 in microbial fuel cell. J Microbiol 2015; 35 (1): 35-9.

[49] Rabaey K, Boon N, Höfte M, Verstraete W. Microbial phenazine production enhances electron transfer in biofuel cells. Environ Sci Technol 2005; 39(9): 3401-8. [http://dx.doi.org/10.1021/es048563o] [PMID: 15926596]

[50] Zhang J, Ni J, Zhou S. Progress in research of microbial fuel cells based on Fe(III)-reducing bacteria. Chin J Appl Environ Biol 2008; 14: $290-5$.

[51] Arbianti R, Utami TS, Hermansyah H, et al. Performance optimization of microbial fuel cell (MFC) using Lactobacillus bulgaricus. Makara Seri Teknologi 2013; 17: 32-8.

[52] Zuo Y, Xing D, Regan JM, Logan BE. Isolation of the exoelectrogenic bacterium Ochrobactrum anthropi YZ-1 by using a U-tube microbial fuel cell. Appl Environ Microbiol 2008; 74(10): 3130-7. [http://dx.doi.org/10.1128/AEM.02732-07] [PMID: 18359834]

[53] Deng L, Li F, Zhou SG, et al. A study of electron-shuttle mechanism in Klebsiella pneumoniae based-microbial fuel cells. Chin Sci Bull 2010; 55: 99-104.

[http://dx.doi.org/10.1007/s11434-009-0563-y]

[54] Holmes DE, Nicoll JS, Bond DR, Lovley DR. Potential role of a novel psychrotolerant member of the family Geobacteraceae, Geopsychrobacter electrodiphilus gen. nov., sp. nov., in electricity production by a marine sediment fuel cell. Appl Environ Microbiol 2004; 70(10): 6023-30.

[http://dx.doi.org/10.1128/AEM.70.10.6023-6030.2004] [PMID: 15466546]

[55] Li Y, Sun YM, Kong XY, et al. Progress in research of electrigens in microbial fuel cell. Microbiology 2009; 36: 1404-9.

[56] Liu M, Shao J, Zhou B, et al. Progress in research of microbial electricigenic respiration. Chin J Appl Environ Biol 2010; 16(3): 445-52. [http://dx.doi.org/10.3724/SP.J.1145.2010.00445]

[57] Schröder U. Anodic electron transfer mechanisms in microbial fuel cells and their energy efficiency. Phys Chem Chem Phys 2007; 9(21): 2619-29. [http://dx.doi.org/10.1039/B703627M] [PMID: 17627307]

[58] Fapetu S, Keshavarz T, Clements M, Kyazze G. Contribution of direct electron transfer mechanisms to overall electron transfer in microbial fuel cells utilising Shewanella oneidensis as biocatalyst. Biotechnol Lett 2016; 38(9): 1465-73. [http://dx.doi.org/10.1007/s10529-016-2128-x] [PMID: 27193895]

[59] Wrighton KC, Thrash JC, Melnyk RA, et al. Evidence for direct electron transfer by a gram-positive bacterium isolated from a microbial fuel cell. Appl Environ Microbiol 2011; 77(21): 7633-9. [http://dx.doi.org/10.1128/AEM.05365-11] [PMID: 21908627]

[60] Logan BE, Regan JM. Electricity-producing bacterial communities in microbial fuel cells. Trends Microbiol 2006; 14(12): 512-8. [http://dx.doi.org/10.1016/j.tim.2006.10.003] [PMID: 17049240]

[61] Gorby YA, Yanina S, McLean JS, et al. Electrically conductive bacterial nanowires produced by Shewanella oneidensis strain MR-1 and other microorganisms. Proc Natl Acad Sci USA 2006; 103(30): 11358-63. [http://dx.doi.org/10.1073/pnas.0604517103] [PMID: 16849424]

[62] Malvankar NS, Lovley DR. Microbial nanowires for bioenergy applications. Curr Opin Biotechnol 2014; $27: 88-95$. [http://dx.doi.org/10.1016/j.copbio.2013.12.003] [PMID: 24863901]

[63] Reguera G. Electron transfer at the cell-uranium interface in Geobacter spp. Biochem Soc Trans 2012; 40(6): 1227-32. [http://dx.doi.org/10.1042/BST20120162] [PMID: 23176459]

[64] Liu L, Xiao Y, Wu Y, et al. Electron transfer mediators in microbial electrochemical systems. Prog Chem 2014; 26(11): 1859-66.

[65] Zhang Y, Zhao Q, Li W. Research advances in microbial electron transfer of bio-electrochemical system. Dev Energy Sci $2014 ; 2$ (4): 39-46. 
[66] Chen H, Zheng P, Xie Z, et al. Principle, components and performance of Shewanella fuel cell. Environ Sci Technol 2014; 37(10): 37-41.

\section{(C) Fan and Xue; Licensee Bentham Open}

This is an open access article licensed under the terms of the Creative Commons Attribution-Non-Commercial 4.0 International Public License (CC BY-NC 4.0) (https://creativecommons.org/licenses/by-nc/4.0/legalcode), which permits unrestricted, non-commercial use, distribution and reproduction in any medium, provided the work is properly cited. 